\title{
Isolation and identification of a lethal rhabdovirus from farmed rice field eels Monopterus albus
}

\author{
Tong Ou, Ruo-Lin Zhu, Zhong-Yuan Chen, Qi-Ya Zhang* \\ State Key Laboratory of Freshwater Ecology and Biotechnology, Institute of Hydrobiology, Chinese Academy of Sciences, \\ Graduate University of Chinese Academy of Sciences, Wuhan 430072, PR China
}

\begin{abstract}
We provide the first description of a virus responsible for a systemic hemorrhagic disease causing high mortality in farmed rice field eels Monopterus albus in China. Typical signs exhibited by the diseased fish were extensive hemorrhages in the skin and viscera and some neurological signs, such as loss of equilibrium and disorganized swimming. Histopathological examination revealed various degrees of necrosis within the spleen and liver. Virus isolation was attempted from visceral tissues of diseased fish by inoculation on 6 fish cell lines. Typical cytopathic effects (CPE) were produced in bluegill fry (BF2) cells, so this cell line was chosen for further isolation and propagation of the virus. Electron microscopy observation showed that the negative stained viral particles had the characteristic bullet shape of rhabdoviruses and an estimated size of $60 \times 120 \mathrm{~nm}$. We therefore tentatively refer to this virus as Monopterus albus rhabdovirus (MoARV). Molecular characterization of MoARV, including sequence analysis of the nucleoprotein $(\mathrm{N})$, phosphoprotein $(\mathrm{P})$, and glycoprotein $(\mathrm{G})$ genes, revealed 94.5 to $97.3 \%$ amino acid similarity to that of Siniperca chuatsi rhabdovirus. Phylogenetic analysis based on the amino acid sequences of $\mathrm{N}$ and $\mathrm{G}$ proteins indicated that MoARV should be a member of the genus Vesiculovirus. Koch's postulates were fulfilled by infecting healthy rice field eels with MoARV, which produced an acute infection. RT-PCR analysis demonstrated that MoARV RNA could be detected in both naturally and experimentally infected fish. The data suggest that MoARV was the causative pathogen of the disease.
\end{abstract}

KEY WORDS: Fish viral disease - Rice field eel - Monopterus albus rhabdovirus - MoARV · Histopathology $\cdot$ Electron microscopy $\cdot$ Phylogenetic analysis

Resale or republication not permitted without written consent of the publisher

\section{INTRODUCTION}

The rice field eel Monopterus albus is an economically important freshwater fish characterized by the ability to breathe air and by the natural occurrence of sex reversal (Zhou et al. 2011). The species belongs to the teleost family Synbranchidae of the order Synbranchiformes (Neoteleostei, Teleostei, Vertebrata), and is distributed mainly in Asia (Jang et al. 2006). With its high culinary value both in taste and nutrients, and its medicinal properties, this fish is a regionally popular food in the Asian diet, and its farming in China has developed rapidly in recent years (Weng et al. 2011). Some lethal dis- eases causing mass mortalities of rice field eels have occurred in farms (Shen et al. 2001). In the spring of 2011, a previously undescribed infectious and lethal disease was observed in farmed rice field eels in Hubei Province. Typical clinical signs exhibited by the diseased fish were extensive red foci in the skin and neurological signs, such as loss of equilibrium and disorganized swimming. Examination of the diseased fish failed to reveal pathogenic bacteria or parasitic agents, which suggested that the systemic hemorrhagic disease may have a viral etiology.

Several lethal viruses, such as Siniperca chuatsi rhabdovirus (SCRV), Chinese sucker rhabdovirus (CSRV), and Scophthalmus maximus rhabdovirus 
(SMRV), have been identified and isolated from diseased mandarin fish Siniperca chuatsi (Zhang \& Li 1999), Chinese sucker Mухосурrinus asiaticus (Zhang et al. 2000), and turbot Scophthalmus maximus (Zhang et al. 2007), respectively. These viruses have been reported to be associated with high morbidity and mortality in a number of aquaculture species and have tentatively been assigned to the family Rhabdoviridae. Rhabdoviruses have a serious socio-economic impact on aquaculture, particularly infectious hematopoietic necrosis virus (IHNV), viral hemorrhagic septicemia virus (VHSV), and spring viremia of carp virus (SVCV), which are all responsible for major disease epizootics in aquaculture and generally result in an acute hemorrhagic syndrome (Betts et al. 2003, Crane \& Hyatt 2011).

In this study, we collected diseased fish showing typical signs and attempted to isolate a virus. Based on a series of observations and analysis, a rhabdovirus was identified as the causative pathogen responsible for the systemic hemorrhagic disease. This is the first disease caused by a virus to be recorded in rice field eels.

\section{MATERIALS AND METHODS}

\section{Sample collection and histopathology study}

In April 2011, a total of 15 diseased rice field eels (mean weight $=180 \mathrm{~g}$ ) showing systemic hemorrhagic syndrome were collected from a farm located in Wuhan, Hubei Province, China. Data were collected on overall diseased fish condition including size, observable lesions, and organ coloration. Visceral organs (pools of spleen, liver, and kidney) were excised and homogenized in phosphatebuffered saline (PBS) containing antibiotics (penicillin, $100 \mathrm{IU} \mathrm{ml}^{-1}$; streptomycin, $100 \mu \mathrm{g} \mathrm{ml}^{-1}$ ). For each pool, the tissue homogenate was stored overnight at $-20^{\circ} \mathrm{C}$, thawed, and then clarified by centrifugation at $4000 \times g\left(15 \mathrm{~min}\right.$ at $\left.4^{\circ} \mathrm{C}\right)$. The supernatant was filtered $(0.45 \mu \mathrm{m}$ pore membrane, Millipore) and stored frozen at $-80^{\circ} \mathrm{C}$ until assayed for virus.

Spleens and livers were dissected from all individuals and processed for histology using standard histological techniques. Each sample was fixed in 10\% phosphate-buffered formalin and embedded in paraffin wax. Paraffin-embedded tissues were serially sectioned $(5 \mu \mathrm{m})$, and stained with Mayer's hematoxylin and eosin (H\&E). Sections were examined by light microscopy for pathological examination.

\section{Cell cultures and virus isolation}

In total, we used 8 cell lines: bluegill fry (BF2; American Type Culture Collection [ATCC] catalog no. CCL 91), Ctenopharyngodon idellus kidney (CIK; Zuo et al. 1986), carp leucocytes (CLC; Faisal \& Ahne 1990), epithelioma papulosum cyprini (EPC; ATCC catalog no. CRL-2872), grass carp fins (GCF; Lu et al. 1990), grass carp ovary (GCO; Zhang et al. 2000), chinook salmon embryo (CHSE-214; ATCC catalog no. CRL 1681), and fathead minnow (FHM; ATCC catalog no. CCL 42). The cells were grown at $25^{\circ} \mathrm{C}$ in TC 199 medium with $10 \%$ fetal bovine serum (FBS).

Primary viral isolation was conducted in BF2, CIK, CLC, EPC, GCF, and GCO cells in 24-well plates with TC 199 medium containing 5\% FBS and $20 \mathrm{mmol} \mathrm{l}^{-1}$ Hepes ( $N$-2-hydroxyethylpiperazine- $N$ ethane-sulfonic acid). After the stored filtered supernatant was thawed at room temperature, 3 consecutive 10-fold dilutions of the tissue sample supernatant were inoculated onto cultured cells in 24 -well plates. The original viral isolate was adapted to cell culture through 3 successive blind passages on these cell lines. In order to obtain a cloned infectious agent, plaque formation was performed to further isolate individual viruses as described previously (Tao et al. 2007, He et al. 2012). Briefly, BF2 cells were infected with the original viral isolate and harvested at $72 \mathrm{~h}$ post infection. The harvested virus suspension was serially diluted and inoculated onto the BF2 cell monolayer grown on a 24-well plate. After adsorption for $1.5 \mathrm{~h}$, the virus suspension was removed and the infected cells were cultured in TC 199 medium containing $0.7 \%$ melted soft agar. When the plaques appeared and developed to $4-5 \mathrm{~mm}$ in diameter, a single plaque was selected to infect fresh cells. A new round of viral infection and plaque isolation was conducted as above until homogeneous plaques appeared. The plaque-isolated virus was designated as Monopterus albus rhabdovirus (MoARV).

\section{Susceptibilities of cell lines}

The susceptibilities of different fish cell lines to MoARV were tested using BF2, CHSE, EPC, and FHM. The viral titers of MoARV in these cell lines were measured by the tissue culture infectious dose $50\left(\mathrm{TCID}_{50}\right) \mathrm{ml}^{-1}$ method as previously described (Zhang et al. 2007). The cytopathic effect (CPE) induced by MoARV was observed under the light microscope. 
Virus purification and electron microscope observation

Cell cultures were grown to confluent monolayer, infected with MoARV, and incubated at $25^{\circ} \mathrm{C}$ until $\mathrm{CPE}$ was complete. Cell cultures were harvested, and cell debris was removed by centrifugation at $8000 \times g(45 \mathrm{~min})$. Virus particles were pelleted by centrifugation at $110000 \times g$ (Beckman SW 41; $1.5 \mathrm{~h}$ at $4^{\circ} \mathrm{C}$ ). The virus pellet was resuspended in $50 \mu \mathrm{l}$ TE buffer $(10 \mathrm{mM}$ Tris-cl, 1 mM EDTA, pH 7.5). The concentrated virus particles were negatively stained with $2 \%(\mathrm{w} / \mathrm{v})$ uranyl acetate and examined with a JEM1230 transmission electron microscope.

\section{RNA extraction}

MoARV-infected cell cultures were harvested after the appearance of CPE as follows: the culture medium was removed and the adherent cells were digested with $0.25 \%$ trypsin solution prior to centrifugation $(800 \times g, 15 \mathrm{~min})$, and subsequent total RNA was extracted from the harvested cell cultures using TRIzol Reagent (Invitrogen) according to the manufacturer's instructions. The resulting RNA was resuspended in DEPC-treated water and stored at $-80^{\circ} \mathrm{C}$ until use.

\section{RT-PCR amplification and sequencing}

The extracted RNA was used as template for RTPCR amplification of MoARV genes, and total RNA extracted from mock-infected cells was used as the negative control. Firstly, one pair of degenerate primers, designated as MoARV-Fn and MoARV-Rn (Table 1), was designed and synthesized according to the conserved nucleoprotein $(\mathrm{N})$ gene sequences of fish rhabdoviruses (Tao et al. 2007). The cDNA was synthesized in a $25 \mu \mathrm{l}$ reaction volume containing 100 pmol random primer, 200 U M-MLV reverse transcriptase (Promega), 1× M-MLV RT reaction buffer, $50 \mu \mathrm{M}$ dNTPs, $40 \mathrm{U}$ of RNase inhibitor, and $5 \mu \mathrm{RNA}$ extracted above. The following PCR was performed in a volume of $25 \mu \mathrm{l}$, containing $0.5 \mathrm{U}$ of Taq polymerase (TransGen), $1 \times$ Taq buffer, $0.2 \mu \mathrm{M}$ of each primer, $0.2 \mathrm{mM}$ dNTPs, and $1 \mu \mathrm{l}$ cDNA. A PCR program was carried out as follows: pre-denaturation at $94^{\circ} \mathrm{C}$ for 5 min; 32 cycles of denaturation at $94^{\circ} \mathrm{C}$ for $30 \mathrm{~s}$, annealing at $55^{\circ} \mathrm{C}$ for $30 \mathrm{~s}$, and extension at $72^{\circ} \mathrm{C}$ for $1.5 \mathrm{~min}$; followed by a final extension step of $72^{\circ} \mathrm{C}$ for $10 \mathrm{~min}$. The PCR products were analyzed by electrophoresis in $1 \%$ agarose gel and visualized under a gel imaging analysis system (Syngene G: Box) after staining with ethidium bromide. The target fragment was purified using a Silica Bead DNA Gel Extraction Kit according to the manufacturer's protocol (Fermentas), cloned into pMD-18T vector (TaKaRa), and sequenced in both directions using an automated ABI sequencer (Sangon).

\section{Sequence comparison and phylogenetic analysis}

The nucleotide and deduced amino acid sequences were analyzed using the EditSeq program (Lasergene). Full length $\mathrm{N}$, phosphoprotein (P), and glycoprotein $(\mathrm{G})$ protein sequences were selected from 13 other completely sequenced rhabdoviruses in GenBank (see legend of Table 2 for GenBank accession numbers). Protein sequences were aligned with Clustal X 1.83 and the homology percentages of N, P, and $G$ proteins of MoARV with the corresponding proteins of other rhabdoviruses were calculated using the Clustal W method in the MegAlign program (Thompson et al. 1994). Phylogenetic trees were constructed using a neighbor-joining (NJ) method as implemented in MEGA version 4 (Tamura et al. 2007).

\section{Experimental challenge and RT-PCR detection}

A total of 30 healthy rice field eels, with a mean weight of approximately $8 \mathrm{~g}$, were randomly split 
into an experimental group and a control group, each containing 15 fish. The fish were acclimated in $0.25 \mathrm{~m}^{3}$ tanks with flow-through aerated water at a temperature of about $25^{\circ} \mathrm{C}$ prior to experimental infection. The fish in the experimental group were challenged by an intraperitoneal injection with $0.05 \mathrm{ml}$ culture medium containing $10^{6} \mathrm{TCID}_{50}$ of MoARV prepared from BF2 cells. In the control group, the fish were mock-infected in the same way using uninfected BF2 cell culture medium. The development of clinical signs and mortality was monitored daily for $2 \mathrm{wk}$, and inoculated or control fish were randomly sampled and tested for the presence of MoARV by RT-PCR. Spleen and liver tissues were also collected for histopathological examination and processed as described above.

The livers of all sampled fish, which were randomly selected from the naturally-infected diseased fish and experimental fish, were dissected from each individual, and tissue samples were examined for the presence of MoARV by RT-PCR as described above. A $\beta$-actin PCR was used as an internal control.

\section{RESULTS}

\section{Clinical signs, gross pathology, and histopathology}

Lethargy and anorexia were the first signs of the disease. In contrast to healthy fish, the sick fish gasped at the surface of the water and their movements became agitated. Prior to death, abnormal clinical signs included loss of equilibrium, disorganized swimming, accumulation of skin mucus, and regular/irregular red spots (approximately $1 \mathrm{~mm}$ in diameter) on the skin of the head, back, abdomen, and caudal trunk. In moribund fish, numerous reddened areas became more obvious, and the anus was red and swollen (Fig. 1A,B). Upon necropsy, the abdominal cavity usually contained clear or bloody ascitic fluid, and the alimentary tract was almost free of food. The spleen was swollen, the gallbladder reddened, and the liver discolored with multiple red foci (2 3 mm; Fig. 1C).

Histopathological changes were investigated in the spleen and liver from diseased fish and compared with the corresponding organs from healthy individuals. The results revealed various degrees of damage and necrosis within the diseased fish spleen and liver. Spleen tissue sections from diseased fish exhibited widespread multifocal necrosis and varioussized cavities (Fig. 2A). Liver damage in diseased fish ranged from focal to locally extensive nuclear pyknosis and cytoplasmic degeneration to generalized hemorrhagic hepatocellular necrosis (Fig. 2B). No pathological changes were observed in tissue sections from healthy fish (data not shown).

\section{Isolation, morphology, and cell infection of MoARV}

Primary viral isolation was conducted in BF2, CIK, CLC, EPC, GCF, and GCO cells. After 3 successive blind passages on these cell lines, the BF2 cell line was found to be the most susceptible to the original viral isolate, and typical CPE was observed in the cell monolayer at $72 \mathrm{~h}$ post infection. In the GCO and

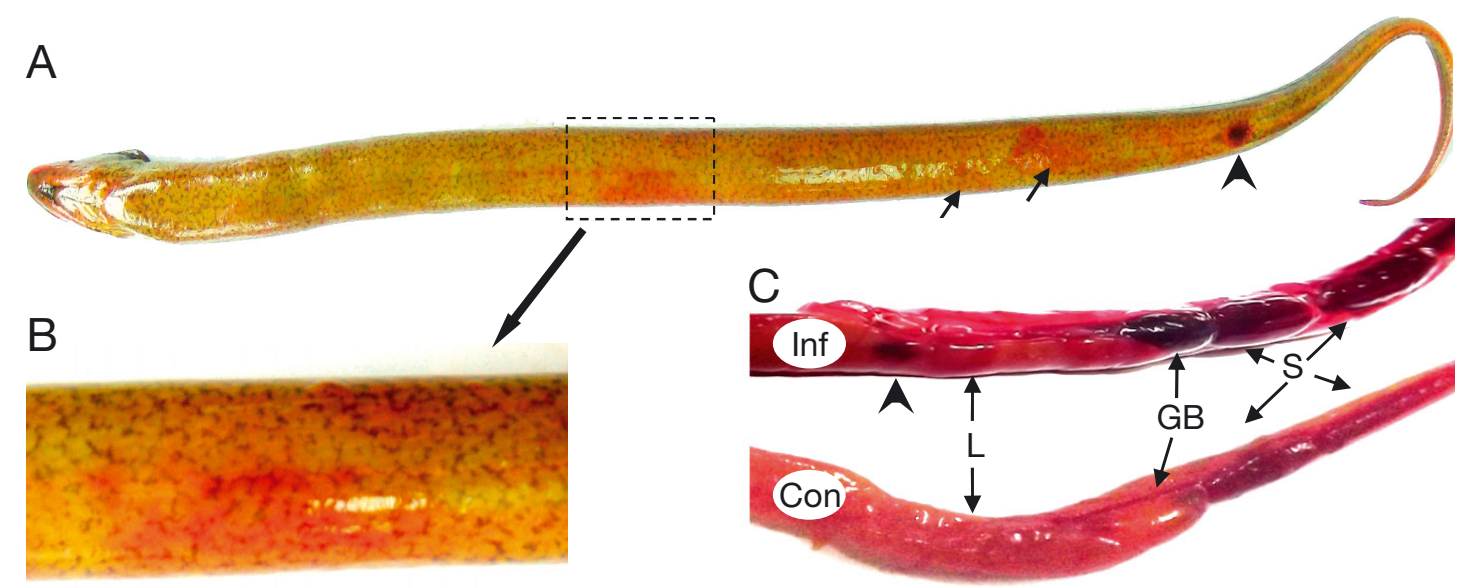

Fig. 1. Monopterus albus infected with Monopterus albus rhabdovirus (MoARV). (A) Gross external appearances of an infected fish with red swollen anus (arrowhead) and regular/irregular red foci (arrows) in the skin. (B) Detail of red foci in the abdomen. (C) Gross appearance of the spleen (S), gallbladder (GB), and liver (L) in MoARV-infected (Inf) and normal uninfected (Con) fish. The internal organs of MoARV-infected fish displayed signs including swollen spleen, reddened gallbladder, and discolored liver with irregular red foci (arrowhead) 


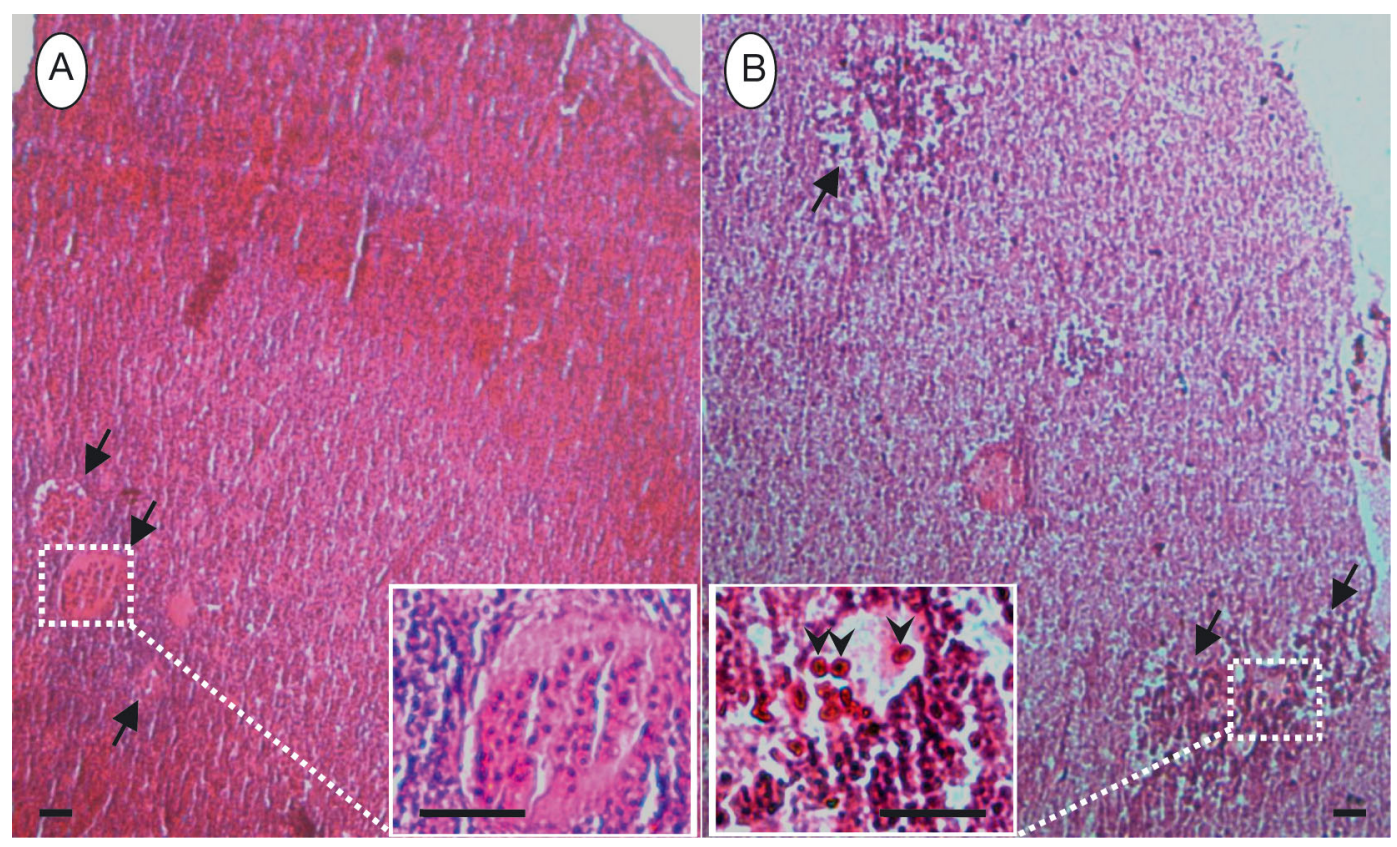

Fig. 2. Monopterus albus infected with Monopterus albus rhabdovirus. Photomicrographs of hematoxylin and eosin-stained tissue sections illustrating lesions. (A) Widespread multifocal necrosis (arrows) and various size cavities in the diseased fish spleen. Inset shows spleen necrosis at higher magnification. (B) Locally extensive necrosis (arrows) with erythrocyte infiltration in the diseased fish liver. Inset shows liver necrosis with erythrocyte infiltration (arrowheads) at higher magnification. Scale bars $=100 \mu \mathrm{m}$

GCF cell lines, the original viral isolate showed moderate infectivity. No obvious CPE was produced in the other 3 cell lines within $1 \mathrm{wk}$ post incubation. Therefore, the BF2 cell line was used to further isolate the original viruses by plaque formation. After 3 rounds of propagation and selection in BF2 cells, homogeneous plaques were formed with a diameter of about $6 \mathrm{~mm}$ (Fig. 3B), instead of the varied plaque sizes formed by the original viral isolate (Fig. 3A). This suggests that the plaque-isolated virus represents a cloned infectious agent.

Electron microscopy observations showed that the negative stained virions had the characteristic bullet shape of rhabdoviruses and an estimated size of $60 \times 120 \mathrm{~nm}$ (Fig. 4). Based upon the morphological features, the plaqueisolated virus is likely to be a member of the family Rhabdoviridae, and was provisionally named Monopterus albus rhabdovirus (MoARV).

The susceptibilities of different fish cell lines to MoARV were tested using
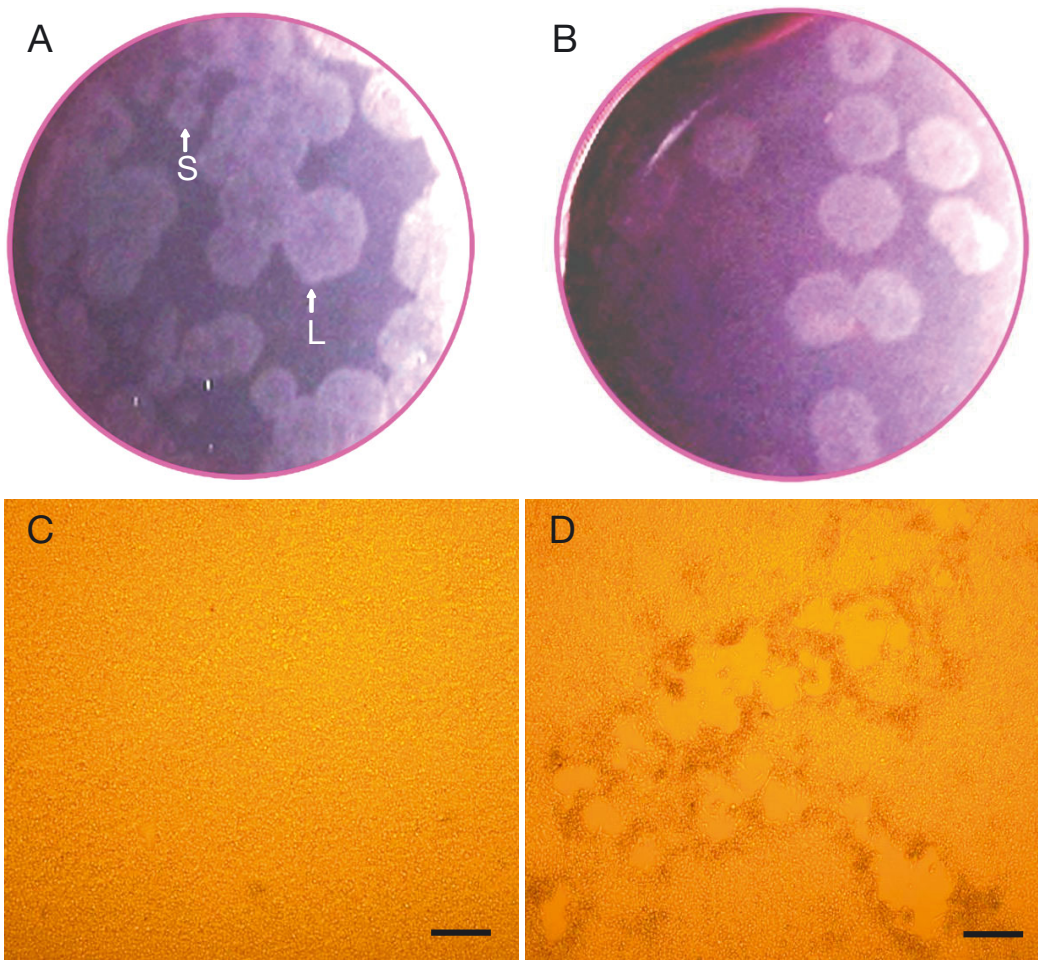

Fig. 3. Plaque formation and cytopathic effects (CPE) in bluegill fry cell culture. (A) Various plaques with diameters ranging from 2 (S) to 8 (L) mm formed by original viral isolate. (B) Homogeneous plaques with a diameter of about $6 \mathrm{~mm}$ formed by plaque-isolated virus. (C) Uninfected control cultures. (D) Typical $\mathrm{CPE}$ induced by Monopterus albus rhabdovirus. Scale bars $=500 \mu \mathrm{m}$ 


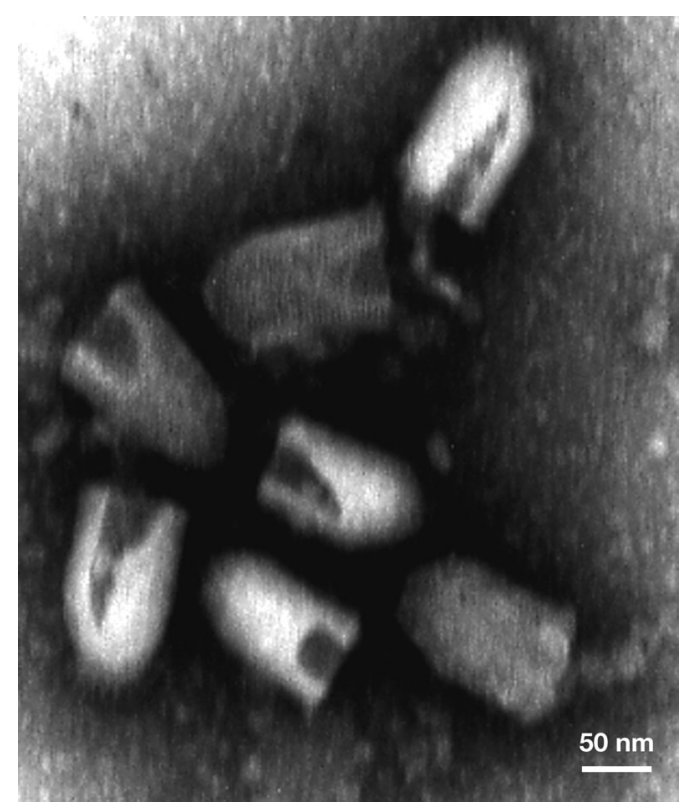

Fig. 4. Transmission electron micrograph of Monopterus albus rhabdovirus particles isolated from the infected bluegill fry cell culture. The negatively stained virions display the characteristic bullet shape of rhabdoviruses

BF2, CHSE, EPC, and FHM, and the resultant viral titers were $10^{7.7}, 10^{7.7}, 10^{4.0}$, and $0 \mathrm{TCID}_{50} \mathrm{ml}^{-1}$, respectively. Significant CPE was observed in BF2 cells at $48 \mathrm{~h}$ post infection with MoARV at a multiplicity of infection of approximately 0.1 (Fig. 3D), while no CPE was observed in the mock-infected cells (Fig. 3C).

\section{Nucleotide and deduced amino acid sequences of MoARV N, $\mathrm{P}$, and G genes}

A homology search for the resulting sequence was conducted using the BLAST program from NCBI, which showed high similarity to the SCRV N gene (Tao et al. 2008). Therefore, 3 pairs of primers (Table 1) were designed and synthesized according to the complete genome sequence of SCRV, and used to clone MoARV N, P, and G genes. The RT-PCR amplification and cloning results are shown in Fig. 5. Nonspecific DNA fragments in the control were confirmed by sequencing. The 3 fragments of MoARV N, $P$, and $G$ genes were amplified and cloned by RTPCR from MoARV-infected BF2 cell cultures, and the corresponding sequences have been deposited in GenBank under accession nos. KF184325, KF184326, and KF184324, respectively. The $\mathrm{N}$ gene is $1456 \mathrm{nt}$ long from the consensus mRNA start sequence AACAG to the transcription stop signal ATG AAA AAA A. The open reading frame (ORF) of the $\mathrm{N}$ gene (1290 nt) is predicted to encode a 429 amino acid protein. The P gene is composed of $971 \mathrm{nt}$, and comprises an 864 nt ORF encoding a 287 amino acid protein. The G gene comprises 1658 nt and includes a 1527 nt ORF, leading to a 508 amino acid protein.

Homology analysis (Table 2) indicated that the $\mathrm{G}$ protein is the most conserved (19.4-97.3\% similarity), followed by the $\mathrm{N}$ protein (13.3-96.5\% similarity) and the P protein (11.9-94.5\% similarity). The N, $\mathrm{P}$, and $\mathrm{G}$ protein sequences of SCRV all showed the highest amino acid sequence similarity to those of MoARV (96.5, 94.5, and 97.3\%, respectively), followed by eel virus European X (EVEX; 43.9, 22.5, and $40.0 \%$, respectively). The analysis also revealed that MoARV showed higher similarity to vesiculoviruses than to novirhabdoviruses.

\section{Phylogenetic analysis}

To investigate the phylogenetic relationships of MoARV within the family Rhabdoviridae, the complete sequences of MoARV $\mathrm{N}$ and $\mathrm{G}$ proteins were used to construct phylogenetic trees with 13 other rhabdoviruses based on the homology analysis and
Fig. 5. RT-PCR cloning of nucleoprotein $(\mathrm{N})$, phosphoprotein $(\mathrm{P})$, and glycoprotein (G) genes of Monopterus albus rhabdovirus (MoARV) from MoARV-infected bluegill fry cell culture. M: DL2000 DNA marker; Actin: internal control gene. The fragments with the approximate sizes of 1600,1100 , and $1800 \mathrm{bp}$ are the target fragments for $\mathrm{N}, \mathrm{P}$, and $\mathrm{G}$ genes, respectively

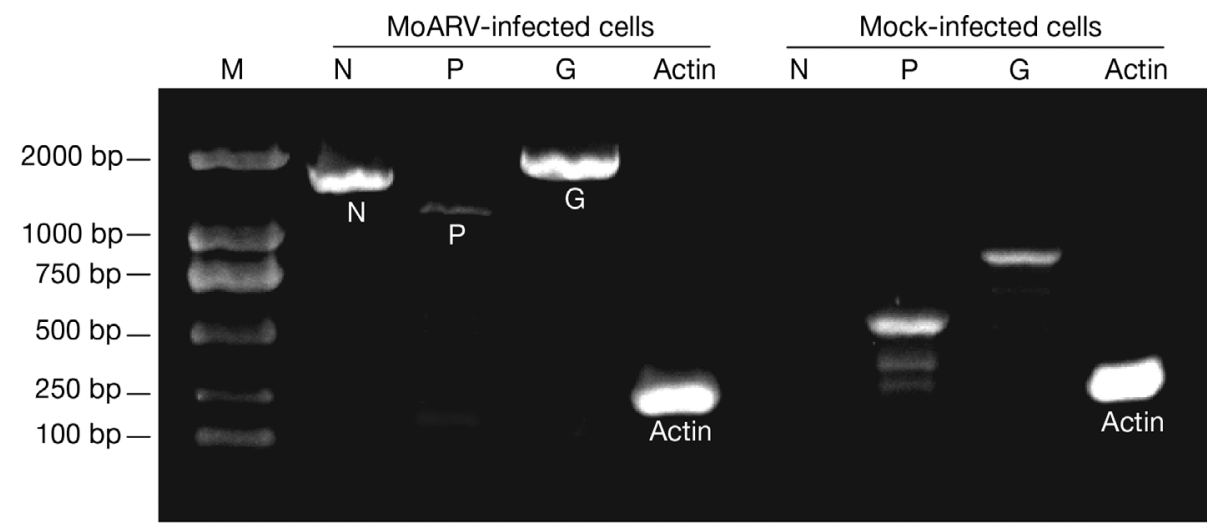


Table 2. Comparison of the amino acid sequences of Monopterus albus rhabdovirus (MoARV) and other rhabdoviruses: SCRV (Siniperca chuatsi rhabdovirus; GenBank accession no. NC008514), EVEX (eel virus European X; FN557213), PFRV (pike fry rhabdovirus; FJ872827), SVCV (spring viremia of carp virus; NC002803), VSNJV (vesicular stomatitis New Jersey virus; P04881, P04877, and P04882), HIRRV (hirame rhabdovirus; NC005093), IHNV (infectious hematopoietic necrosis virus; NC001652), SHRV (snakehead rhabdovirus; NC000903), VHSV (viral hemorrhagic septicemia virus; NC000855), ADRV (Adelaide River virus; JN935380), BEFV (bovine ephemeral fever virus; NC002526), ABLV (Australian bat lyssavirus; NC003243), RABV (rabies virus; NC001542). The highest values of similarity with MoARV are shown in bold. $\mathrm{N}$ : nucleoprotein; P: phosphoprotein; G: glycoprotein

\begin{tabular}{|c|c|c|c|}
\hline \multirow{2}{*}{$\begin{array}{c}\text { Genus } \\
\text { Virus }\end{array}$} & \multicolumn{3}{|c|}{ Protein name } \\
\hline & $\begin{array}{c}\text { Similar } \\
\mathrm{N}\end{array}$ & $\begin{array}{l}\text { of } \mathrm{Mo} \\
\mathrm{P}\end{array}$ & $\begin{array}{l}\text { oteins to: } \\
\mathrm{G}\end{array}$ \\
\hline \multicolumn{4}{|c|}{ Vesiculovirus } \\
\hline SCRV & 96.5 & 94.5 & 97.3 \\
\hline EVEX & 43.9 & 22.5 & 40.0 \\
\hline PFRV & 39.1 & 17.7 & 39.5 \\
\hline SVCV & 38.2 & 18.9 & 39.3 \\
\hline VSNJV & 35.4 & 18.4 & 35.4 \\
\hline \multicolumn{4}{|c|}{ Novirhabdovirus } \\
\hline HIRRV & 13.9 & 18.5 & 28.1 \\
\hline IHNV & 15.2 & 18.7 & 28.0 \\
\hline SHRV & 13.6 & 17.4 & 28.0 \\
\hline VHSV & 13.3 & 19.4 & 29.2 \\
\hline \multicolumn{4}{|c|}{ Ephemerovirus } \\
\hline ADRV & 32.2 & 11.9 & 19.4 \\
\hline BEFV & 31.5 & 17.0 & 21.2 \\
\hline \multicolumn{4}{|c|}{ Lyssavirus } \\
\hline ABLV & 22.7 & 17.0 & 30.9 \\
\hline RABV & 21.8 & 18.2 & 30.8 \\
\hline
\end{tabular}

multiple alignments. As shown in Fig. 6A, based on $\mathrm{N}$ protein analysis, the 14 rhabdoviruses were divided into 4 groups. MoARV and SCRV clustered together, and further grouped with 4 other rhabdoviruses in the genus Vesiculovirus, including EVEX, pike fry rhabdovirus (PFRV), SVCV, and vesicular stomatitis New Jersey virus (VSNJV). Other rhabdoviruses clustered within the tree were in agreement with the established genera. The tree derived from analysis of $G$ protein sequences showed similar results (Fig. 6B). The phylogenetic analysis revealed that MoARV should belong to the genus Vesiculovirus in the family Rhabdoviridae.

\section{Experimental challenge and RT-PCR detection}

To confirm pathogenicity, an artificially induced infection was performed on healthy rice field eels. BF2-propagated MoARV was used to infect 15 fish by intraperitoneal injection. In general, the disease in experimental fish was indicative of an acute infection. First signs of disease in experimentally infected fish occurred at about $3 \mathrm{~d}$ post infection (dpi), and mortality began at $5 \mathrm{dpi}$. The majority of infected fish died within the first $8 \mathrm{dpi}$, and the final death occurred at $10 \mathrm{dpi}$, resulting in $86.7 \%$ cumulative mortality (Table 3). Moribund fish displayed similar signs and histopathology as described above. In the control group, no mortality or pathological changes were observed in any of the rice field eels. The results indicate that the MoARV is the causative pathogen of the disease.

To detect MoARV infection in rice field eels, a pair of specific primers (Det-F and Det- $\mathrm{R}_{i}$ Table 1 ) derived from the MoARV N gene was used to amplify a target sequence with the predicted length of 743 bp by RTPCR. MoARV was detected by RT-PCR in liver tissue samples of rice field eels which were randomly selected from the original diseased and experimental fish (Fig. 7). A fragment of approximately 750 bp was amplified from naturally infected fish and experimentally MoARV-infected fish, and no corresponding band was detected in the experimental mockinfected fish and those fish collected before injection. As an internal control, $\beta$-actin was amplified from all of the detected fish samples. Therefore, the experimental rice field eels were negative for MoARV before infection and suitable for experimental challenge, and MoARV was detected in both naturally and experimentally infected fish.

\section{DISCUSSION}

In this study, we present data on the pathology, isolation, and characterization of a lethal rhabdovirus responsible for a systemic hemorrhagic disease causing high mortality in farmed rice field eels. The diagnosis of rhabdovirus infection was based on a combination of characteristic pathological changes, virus isolation in fish cell lines, cell infection, electron microscopy observation, molecular characterization, experimental challenge, and RT-PCR detection. This is the first record of a viral pathogen associated with significant morbidity and mortality in farmed rice field eels.

Rhabdoviruses are significant viral pathogens in aquaculture, and usually result in an outbreak of acute disease characterized by systemic hemorrhages or necrotic ulcerations (Johnson et al. 1999, Ahne et al. 2002, Elston \& Meyers 2009, Toplak et al. 2010, Zhang \& Gui 2012). More than 10 species of 


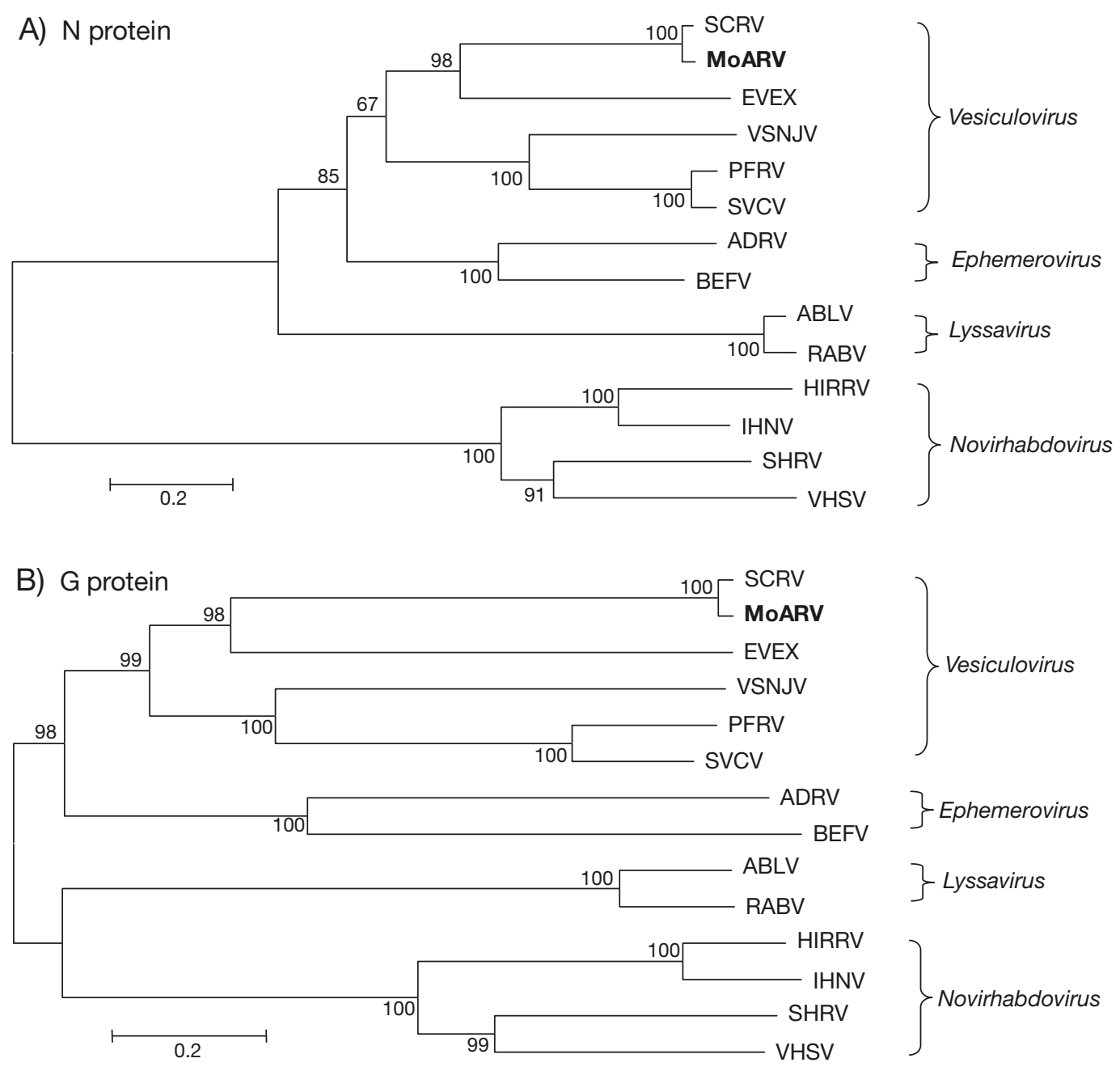

Fig. 6. Phylogenetic relationships of Monopterus albus rhabdovirus (MoARV) to representative rhabdoviruses. The alignment of whole amino acid sequences of (A) nucleoprotein and (B) glycoprotein was used to construct the neighbor-joining trees using the MEGA package. Bootstrap values (\%) for 1000 tree replicates are shown at each branch node. MoARV is shown in bold. Viruses from the same genera are indicated

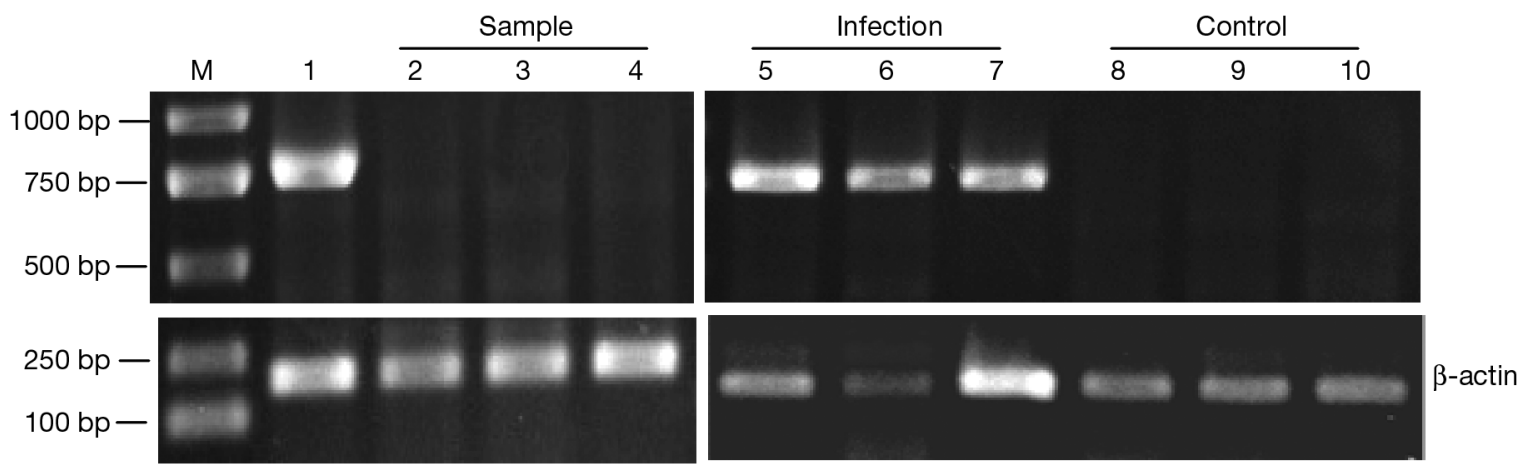

Fig. 7. RT-PCR detecting the infection of Monopterus albus rhabdovirus (MoARV) in Monopterus albus. M: DL2000 DNA marker; Lane 1: the original diseased fish used for isolating virus; Lanes 2-4: random samples of experimental fish collected before infection; Lanes 5-7: random samples from 15 fish in the infected group collected within 5 to $10 \mathrm{~d}$ after infection; Lanes 8-10: random samples from 15 fish in the control group collected $2 \mathrm{wk}$ after mock infection. Every fish liver was examined by RT-PCR using primers for the nucleoprotein gene (Det-F and Det-R, listed in Table 1), and the $\beta$-actin gene was used as an internal control 
Table 3. Monopterus albus. Cumulative mortality of rice field eels after experimental infection with Monopterus albus rhabdovirus; each group contained 15 specimens

\begin{tabular}{|lcccccccccc|}
\hline \multirow{2}{*}{ Groups } & \multicolumn{8}{c|}{ Time (d) } & \multirow{8}{*}{ Final \% } \\
\cline { 2 - 7 } & 4 & 5 & 6 & 7 & 8 & 9 & 10 & 14 & \\
\hline Infected & 0 & 1 & 2 & 6 & 11 & 12 & 13 & 13 & 86.7 \\
Control & 0 & 0 & 0 & 0 & 0 & 0 & 0 & 0 & 0 \\
\hline
\end{tabular}

rhabdoviruses have been isolated from cultured fish, including some important economic species from both fresh and marine water (Meyers et al. 1999, Lumsden et al. 2007, Zhang et al. 2007, Gui \& Zhu 2012). Rice field eels infected with MoARV also exhibited an acute disease characterized by extensive hemorrhages in the skin and viscera. In order to obtain more detail on pathological changes, histopathological examination of the spleen and liver was performed. Focal to extensive necrosis with hemorrhage was observed in these tissues, and similar histopathological changes have been reported associated with other fish viral diseases (Sano 1976, Negele 1977, Chen et al. 2008, Zhang \& Gui 2012). In addition, the virus could replicate well in some cell lines derived from other fish species, such as BF2 and CHSE-214, and produce typical CPE in these cells within as little as $2 \mathrm{~d}$. These data suggest that MoARV is a highly virulent virus causing acute systemic infections and multiple organ damage. Early diagnosis of MoARV is required in order to avoid large disease outbreaks in rice field eel farming. In this study, a pair of specific primers based on the MoARV N gene was designed and used for RT-PCR detection of MoARV in rice field eels. The $\mathrm{N}$ gene, as the most highly expressed gene in members of the family Rhabdoviridae, is usually considered an ideal target for PCR-based diagnostic methods (Talbi et al. 2011). The results indicated that MoARV RNA could be detected in naturally and experimentally infected fish, and RT-PCR detection with diagnostic primers is an effective method for the diagnosis of MoARV infection in the farmed rice field eels and other fish.

Rhabdoviruses have nonsegmented and singlestranded RNA genomes encoding 5 major functional proteins, namely the $\mathrm{N}, \mathrm{P}$, matrix protein $(\mathrm{M}), \mathrm{G}$, and RNA-dependent RNA polymerase (L) in the order 3' N-P-M-G-L 5' (Zhu et al. 2011). Significantly, MoARV $\mathrm{N}, \mathrm{P}$, and $\mathrm{G}$ proteins all have the highest amino acid similarities (94.5-97.3\%) to those of SCRV. For the MoARV N and G proteins, the highest similarities (35.4-97.3\%) are to members of the genus Vesiculo- virus. The family Rhabdoviridae currently includes 6 genera: Vesiculovirus, Lyssavirus, Ephemerovirus, Novirhabdovirus, Cytorhabdovirus, and Nucleorhabdovirus (Tordo et al. 2005), and to date all reported rhabdoviruses infecting fish have been classified in the genera Vesiculovirus or Novirhabdovirus (Galinier et al. 2012). Phylogenetic analysis also revealed SCRV as the closest relative of MoARV, and they were further grouped with the recently characterized EVEX. Moreover, these viruses formed a genetic cluster distinct from the one represented by SVCV and PFRV, supporting the potential existence of a new fish vesiculovirus clade as previously reported (Galinier et al. 2012, Stone et al. 2013). Rice field eels belong to the Synbranchiformes, whose members are taxonomically closely related to those of the Perciformes (Johnson \& Patterson 1993). SCRV was originally isolated from mandarin fish (also called Chinese perch) (Zhang \& Gui 2012). Rhabdoviruses infecting mandarin fish and rice field eels are of particular interest, since their impact on percid farming is increasing in Europe after the first record of a rhabdovirus pathogenic for perch in France in 1980 (Dorson et al. 1984). The phylogenetic study performed by Talbi et al. (2011) showed that all rhabdoviruses from perch, as well as SCRV and EVEX, were clustered together. Stone et al. (2013) proposed the new genus Perhabdovirus for the fish rhabdoviruses and created 3 further species, viz. Perch rhabdovirus, Anguillid rhabdovirus, and Sea trout rhabdovirus, within the new genus. Although SCRV was not included in the genus Perhabdovirus, it was closely related to the proposed members of this genus. EVEX was considered a member of the species Anguillid rhabdovirus (Stone et al. 2013). After EVEX was isolated in a shipment of European elvers Anguilla anguilla from France to Tokyo, another rhabdovirus appearing to be serologically similar to EVEX was reported in Japan (Kobayashi \& Miyazaki 1996, Galinier et al. 2012). This information suggests that rhabdoviruses also have a noticeable impact on percid farming in Asia and may evolve to infect taxonomically related host species. Isolation and characterization of a rhabdovirus from farmed rice field eels in China may help us to better understand the evolution and circulation of these rhabdoviruses between regions and hosts.

Acknowledgements. This work was supported by grants from the National Major Basic Research Program (2010CB126303), National Natural Science Foundation of China (31072239, 31270213), and the FEBL research grant (2011FBZ12, 2008FBZ16). 


\section{LITERATURE CITED}

Ahne W, Bjorklund HV, Essbauer S, Fijan N, Kurath G, Winton JR (2002) Spring viremia of carp (SVC). Dis Aquat Org 52:261-272

Betts AM, Stone DM, Way K, Torhy C, Chilmonczyk S, Benmansour A, De Kinkelin P (2003) Emerging vesiculo-type virus infections of freshwater fishes in Europe. Dis Aquat Org 57:201-212

> Chen ZY, Liu H, Li ZQ, Zhang QY (2008) Development and characterization of monoclonal antibodies to spring viraemia of carp virus. Vet Immunol Immunopathol 123: 266-276

> Crane M, Hyatt A (2011) Viruses of fish: an overview of significant pathogens. Viruses 3:2025-2046

> Dorson M, Torchy C, Chilmonczyk S, de Kinkelin P, Michel C (1984) A rhabdovirus pathogenic for perch (Perca fluviatilis L.): isolation and preliminary study. J Fish Dis 7 : 241-245

> Elston RA, Meyers TR (2009) Effect of viral hemorrhagic septicemia virus on Pacific herring in Prince William Sound, Alaska, from 1989 to 2005. Dis Aquat Org 83:223-246

> Faisal M, Ahne W (1990) A cell line (CLC) of adherent peripheral blood mononuclear leucocytes of normal common carp Cyprinus carpio. Dev Comp Immunol 14:255-260

- Galinier R, Van Beurden S, Amilhat E, Castric J and others (2012) Complete genomic sequence and taxonomic position of eel virus European X (EVEX), a rhabdovirus of European eel. Virus Res 166:1-12

Gui JF, Zhu ZY (2012) Molecular basis and genetic improvement of economically important traits in aquaculture animals. Chin Sci Bull 57:1751-1760

> He LB, Ke F, Zhang QY (2012) Rana grylio virus as a vector for foreign gene expression in fish cells. Virus Res 163: $66-73$

> Jang S, Zhou F, Xia L, Zhao W, Cheng H, Zhou R (2006) Construction of a BAC library and identification of Dmrt1 gene of the rice field eel, Monopterus albus. Biochem Biophys Res Commun 348:775-780

Johnson DG, Patterson C (1993) Percomorph phylogeny: a survey of acanthomorphs and a new proposal. Bull Mar Sci 52:554-626

> Johnson MC, Maxwell JM, Loh PC, Leong JAC (1999) Molecular characterization of the glycoproteins from two warm water rhabdoviruses: snakehead rhabdovirus (SHRV) and rhabdovirus of penaeid shrimp (RPS)/spring viremia of carp virus (SVCV). Virus Res 64:95-106

Kobayashi T, Miyazaki T (1996) Rhabdoviral dermatitis in Japanese eel, Anguilla japonica. Fish Pathol 31:183-190

> Lu YA, Lannan CN, Rohovec JS, Fryer JL (1990) Fish cell lines: establishment and characterization of three new cell lines from grass carp (Ctenopharyngodon idella). In Vitro Cell Dev Biol 26:275-279

Lumsden JS, Morrison B, Yason C, Russell S and others (2007) Mortality event in freshwater drum Aplodinotus grunniens from Lake Ontario, Canada, associated with viral haemorrhagic septicaemia virus, Type IV. Dis Aquat Org 76:99-111

Meyers TR, Short S, Lipson K (1999) Isolation of the North American strain of viral hemorrhagic septicemia virus (VHSV) associated with epizootic mortality in two new host species of Alaskan marine fish. Dis Aquat Org 38: 81-86

Negele RD (1977) Histopathological changes in some organs of experimentally infected carp fingerlings with Rhabdo- virus carpio. Bull Off Int Epizoot 87:449-450

> Sano T (1976) Viral diseases of cultured fishes in Japan. Fish Pathol 10:221-226

Shen JY, Liu W, Qian D (2001) Studies on the pathogens of haemorrhagic disease of Monopterus albus. J Zhejiang Ocean Univ 20:120-122 (Chinese with English abstract)

> Stone DM, Kerr RC, Hughes M, Radford AD, Darby AC (2013) Characterisation of the genomes of four putative vesiculoviruses: tench rhabdovirus, grass carp rhabdovirus, perch rhabdovirus and eel rhabdovirus European X. Arch Virol 158:2371-2377

Talbi C, Cabon J, Baud M, Bourjaily M, de Boisséson C, Castric J, Bigarré L (2011) Genetic diversity of perch rhabdoviruses isolates based on the nucleoprotein and glycoprotein genes. Arch Virol 156:2133-2144

Tamura K, Dudley J, Nei M, Kumar S (2007) MEGA4: molecular evolutionary genetics analysis (MEGA) software version 4.0. Mol Biol Evol 24:1596-1599

> Tao JJ, Gui JF, Zhang QY (2007) Isolation and characterization of a rhabdovirus from co-infection of two viruses in mandarin fish. Aquaculture 262:1-9

> Tao JJ, Zhou GZ, Gui JF, Zhang QY (2008) Genomic sequence of mandarin fish rhabdovirus with an unusual small non-transcriptional ORF. Virus Res 132:86-96

> Thompson JD, Higgins DG, Gibson TJ (1994) CLUSTAL W: improving the sensitivity of progressive multiple sequence alignment through sequence weighting, position-specific gap penalties and weight matrix choice. Nucleic Acids Res 22:4673-4680

Toplak I, Hostnik P, Rihtarič D, Olesen NJ, Skall HF, Jenčič $\mathrm{V}$ (2010) First isolation and genotyping of viruses from recent outbreaks of viral haemorrhagic septicaemia (VHS) in Slovenia. Dis Aquat Org 92:21-29

Tordo N, Benmansour A, Calisher C, Dietzgen RG and others (2005) Virus taxonomy: Eighth Report of the International Committee on Taxonomy of Viruses. Academic Press, London, p 623-644

> Weng WY, Wu T, Chen WQ, Liu GM, Osatomi K, Su WJ, Cao MJ (2011) Purification and characterization of pepsinogens and pepsins from the stomach of rice field eel (Monopterus albus Zuiew). Fish Physiol Biochem 37: 543-552

Zhang QY, Gui JF (2012) Atlas of aquatic viruses and viral diseases. Science Press, Beijing

> Zhang QY, Li ZQ (1999) Three different viruses observed from the tissues of diseased mandarin fish Siniperca chuatsi. Chin Sci Bull 44:437-441

Zhang QY, Li ZQ, Gui JF (2000) Isolation of a lethal rhabdovirus from the cultured Chinese sucker Myхосурrinus asiaticus. Dis Aquat Org 42:1-9

Zhang QY, Tao JJ, Gui L, Zhou GZ, Ruan HM, Li ZQ, Gui JF (2007) Isolation and characterization of Scophthalmus maximus rhabdovirus. Dis Aquat Org 74:95-105

Zhou QB, Wu HD, Zhu CS, Yan XH (2011) Effects of dietary lipids on tissue fatty acids profile, growth and reproductive performance of female rice field eel (Monopterus albus). Fish Physiol Biochem 37:433-445

> Zhu RL, Lei XY, Ke F, Yuan XP, Zhang QY (2011) Genome of turbot rhabdovirus exhibits unusual non-coding regions and an additional ORF that could be expressed in fish cell. Virus Res 155:495-505

Zuo WG, Qian HX, Xu YF, Du SY, Yang XL (1986) A cell line derived from the kidney of grass carp (Ctenopharyngodon idellus). J Fish China 10:11-17 (Chinese with English abstract) 